\title{
Brand innovator versus multisource cefpodoxime in respiratory tract infections: A comparative study
}

\author{
Snyman JR', Medlen CE ${ }^{2 *}$ \\ ${ }^{1}$ Isimo Health, Belville, Cape Town \\ 2 Department of Pharmacology, University of Pretoria, Pretoria \\ *Corresponding author, email: connie.medlen@up.ac.za
}

\begin{abstract}
Purpose: In everyday practice clinicians are overwhelmed by claims from the pharmaceutical industry and, due to marketing efforts, they often view generic multisource products with scepticism despite proof and registration by regulatory authorities of bioequivalence. The primary aim of this study was exploratory and aimed to compare the acceptability of generic cefpodoxime $\left(\right.$ Cepodem $^{\oplus}$ ) versus the innovator brand product (Orelox ${ }^{\oplus}$ ) in terms of effectiveness, safety and tolerability in a general private practice setting in South Africa in the treatment of upper and lower respiratory tract infections.
\end{abstract}

Methods and patients: Ninety patients were recruited and randomised to receive either product for 10 days after clinical diagnoses of either tonsillo-pharyngitis or rhino-sinusitis or pneumonia.

Results: It was demonstrated that both products resulted in similar clinical and bacteriological cure rates with also no difference in tolerability profiles.

Conclusion: These findings support the bioequivalence data as submitted for regulatory approval, of the generic Cepodem ${ }^{\oplus}$ translating into clinical effectiveness and argues against the need for a clinical non-inferiority study to demonstrate sameness.

Keywords: bioequivalence, cephalosporin, multisource products, upper respiratory tract

\section{Introduction}

Pharmaceutical companies introduced generic medicines into the South African market in the early 1980s, and there has always been resistance against their use. This is mainly due to the perception that the pharmacology of a generic medicine is inferior to an innovator brand-name product. Some clinicians even doubt the efficacy of the generic molecule and may believe generics behave differently in ill patients. The concern is particularly significant in diseases where the effect does not immediately correlate with a clinical parameter (e.g. blood pressure) such as in infectious diseases where the outcome is delayed and often uncertain in some respects.

The aim of antibiotic treatment is to maximise antibacterial activity (clinical effectiveness) while preventing recurrence of infection and the development of resistant pathogens. ${ }^{1,2}$ Furthermore, there is reason to doubt, as an analysis conducted at the Institute of Microbiology, University of Genoa, Italy, demonstrated that some generic formulations of another cephalosporine antimicrobial agent i.e. ceftriaxone failed to achieve the required Pharmacokinetic/Pharmacodynamic (PK/ PD) outcomes to ensure clinical efficacy. ${ }^{3}$ There are thus good arguments and evidence to substantiate the clinical fraternity's distrust in generic substitution.

The pharmacokinetic profile and the subsequent dosing regimen of an antimicrobial will explain the time course of serum antibiotic concentrations. ${ }^{4}$ The pharmacodynamic parameters again are the other factors required for constructing a PK/PD model. ${ }^{5}$ The predictive value of different PK/PD models of an antimicrobial agent in ascertaining the ability thereof to eradicate the causative bacterial pathogen has been investigated in different animal experiments and clinical studies. ${ }^{6}$ The deterministic factor for clinical success for a $\beta$-lactam antibiotic is the length of time that serum concentration exceeds the Minimum Inhibitory Concentration (MIC). ${ }^{6}$ The period by which the antibiotic concentration exceeds the MIC, when expressed as a percentage of the dosing interval, is referred to as the coverage. ${ }^{6}$ The dosing schedules for $\beta$-lactam antibiotics should maintain serum concentrations above the MIC for the more common respiratory tract pathogens for at least $50 \%$ of the dosing interval to ensure clinical success. ${ }^{6} \mathrm{~A}$ good pharmacokinetic profile and a low MIC are thus required for optimal therapeutic efficacy. ${ }^{6,7}$

Upper respiratory tract infections are one of the most common reasons for visits to the doctors' rooms. In children under 15 years of age, otitis media is the most frequent diagnosis made by community physicians. ${ }^{8}$ Other types of upper respiratory tract infections, which are often seen in adults and adolescents, include sinusitis and pharyngitis. Acute bacterial sinusitis is often a difficult clinical diagnosis and a sinus tap is regarded as the gold standard in the diagnosis of bacterial sinusitis, which is, however, a painful and expensive procedure. A throat swab may give an indication of the cause of pharyngitis. Diagnosis of the causative organism is frequently delayed in clinical practice as most clinicians treat empirically without knowing the causative organism at time of scripting an antibiotic. 
Although the majority of upper respiratory tract infections (> 80\%) are viral or start as a viral infection, most of these infections are treated with an antimicrobial drug in general practice. Bacterial organisms implicated in respiratory tract infections are in $80 \%$ of cases one or a combination of the following: S. pneumoniae, H. influenza, Moraxella cattharalis and/or the atypical organisms such as mycoplasma. The latter has a significant seasonal trend.

Cefpodoxime, an oral third generation cephalosporin is indicated for the treatment of upper and lower respiratory tract infections (i.e. sinusitis, acute bronchitis, pharyngitis and tonsillitis and community acquired pneumonia). The data collected from prior experimental and clinical studies demonstrate that cefpodoxime is considered an appropriate choice of treatment for acute otitis media. 9,10

Cefpodoxime is active against penicillin-susceptible S. pneumoniae $\left(\mathrm{MIC}_{90}<0.06 \mathrm{mg} / \mathrm{L}\right.$ to $<0.25 \mathrm{mg} / \mathrm{L}$ ) and penicillin-intermediate resistant strains of $S$. pneumoniae $\left(\mathrm{MIC}_{90}\right.$ 1-2 mg/L). ${ }^{11}$ Cefpodoxime shows good activity against H. influenzae $\left(\mathrm{MIC}_{90} 0.03 \mathrm{mg} / \mathrm{L}\right.$ to $0.13 \mathrm{mg} / \mathrm{L}$ ), including $\beta$ -lactamase-producing strains. ${ }^{11}$ A study from the USA teaches that cefpodoxime exhibited greater in-vitro activity against S. pneumoniae than cefaclor, cefuroxime axetil, cefprozil, cefixime or loracarbef. ${ }^{12}$

Cefpodoxime's excellent PK/PD profile is further substantiated by the fact that it reaches adequate concentrations in the middle-ear fluid of paediatric patients based on recommended dosing frequencies. ${ }^{11,13}$ Cefpodoxime is also stable to hydrolysis by commonly encountered plasmid-mediated $\beta$-lactamases making it particularly useful in the treatment of upper airways infections where $\beta$-lactamases producing organisms are often the source of infection. ${ }^{2}$

Cefpodoxime is ideally suited to research effectiveness of an antimicrobial in empiric treatment (the norm) of respiratory tract infections in the community setting.

Bioavailability of multisource products is consequently critical to be able to claim the same PK/PD parameters and therefore clinical efficacy. ${ }^{14,15}$

Table I. Inclusion and exclusion criteria

\begin{tabular}{|c|c|c|c|}
\hline Condition & Symptoms/Signs & Inclusion criteria & Exclusion criteria \\
\hline Rhinosinusitis & $\begin{array}{l}\text { Major: } \\
\text { Facial pain } \\
\text { Pressure/fullness } \\
\text { Nasal obstruction/blockage } \\
\text { Nasal or postnasal discharge/ } \\
\text { purulence } \\
\text { Hyposmia/anosmia } \\
\text { Fever } \\
\text { Minor: } \\
\text { Headaches } \\
\text { Halitosis } \\
\text { Fatigue } \\
\text { Dental pain } \\
\text { Cough } \\
\text { Ear pain/pressure/fullness }\end{array}$ & $\begin{array}{l}\text { Presence of two or more major } \\
\text { signs and symptoms } \\
\text { Evidence of nasal purulence } \\
\text { Fever and/or facial pain/ } \\
\text { pressure does not constitute } \\
\text { a suggestive history in the } \\
\text { absence of other nasal signs } \\
\text { and symptoms }\end{array}$ & $\begin{array}{l}\text { Failure to respond after } 72 \text { hours of } \\
\text { therapy. } \\
\text { Peri-orbital swelling. } \\
\text { Evidence of CNS extension } \\
\text { (meningism, focal neurological signs, } \\
\text { altered level of consciousness). } \\
\text { Severe systemic illness } \\
\text { Chronic sinusitis } \\
\text { Possible viral sinusitis: sneezing with } \\
\text { watery nasal discharge }\end{array}$ \\
\hline $\begin{array}{l}\text { Mild/moderate tonsillo- } \\
\text { pharyngitis }\end{array}$ & $\begin{array}{l}\text { Mild to moderate pain on swallowing } \\
\text { Fever } \\
\text { Red eyes } \\
\text { Headache } \\
\text { Abdominal pain }\end{array}$ & $\begin{array}{l}\text { Tonsillar erythema and or } \\
\text { purulent exudates } \\
\text { Fever and } \\
\text { Any one of the following } \\
\text { symptoms: } \\
\text { - sore throat } \\
\text { - dysphagia } \\
\text { - mild to moderate pain on } \\
\text { swallowing } \\
\text { - tender cervical lymph nodes }\end{array}$ & $\begin{array}{l}\text { Peritonsillar sepsis including; quinsy } \\
\text { abscess, cellulites, trismus and/or } \\
\text { asymmetrical peritonsillar swelling }\end{array}$ \\
\hline $\begin{array}{l}\text { Broncho-pneumonia/ } \\
\text { community acquired } \\
\text { pneumonia }\end{array}$ & $\begin{array}{l}\text { Pleuritic chest pain } \\
\text { Myalgia, malaise, } \\
\text { fatigue, cough, } \\
\text { fever, dyspnoea, wheezing }\end{array}$ & $\begin{array}{l}\text { Productive cough, } \\
\text { Tachypnoea ( }>24 \text { breaths per } \\
\text { min) } \\
\text { Tachycardia } \\
\text { Fever } \\
\text { Any one of the following chest } \\
\text { signs and symptoms: } \\
\text { - Pleuritic chest pain } \\
\text { - Chest splinting } \\
\text { - Localised crepitations } \\
\text { - Localised bronchial breath } \\
\text { sounds } \\
\text { - Localised dullness to } \\
\text { percussion } \\
\text { - Localised decrease in breath } \\
\text { sounds } \\
\text { - Localised pleural rub }\end{array}$ & $\begin{array}{l}\text { - confusion } \\
\text { - decreased blood pressure: } \\
\text { systolic }<90 \mathrm{mmHg} \\
\text { - } \text { respiratory rate }>20 \\
\text { - } \mathrm{PO}_{2} \text { of less } 90 \% \\
\text { - multilobar consolidation } \\
\text { - extra-thoracic septic complications }\end{array}$ \\
\hline
\end{tabular}


There is significant scope for research to demonstrate clinical effectiveness (real practice setting), tolerability and acceptability of generic multisource brands in practice in order to establish brand trust. The primary aim of this study was exploratory and aimed to compare the acceptability of generic cefpodoxime versus the innovator brand-name product in terms of effectiveness, safety and tolerability in a general private practice setting in South Africa in the treatment of upper and lower respiratory tract infections.

\section{Materials and methods}

\section{Patients}

The study enrolled adult patients diagnosed clinically with mild to moderate bacterial tonsillo-pharyngitis, bacterial sinusitis or pneumonia. All participants were aged $\geq 18$ years and provided written informed consent after ethics committee approval of the study for private practice in South Africa, prior to being enrolled. The study was approved by a private ethics committee i.e. Pharma-Ethics before commencement of the clinical trial. Table I lists the clinical inclusion and exclusion criteria. Patients were excluded from the study if they had been exposed to an antibacterial medicine or treatment in the last 21 days, presented with a history of rheumatic fever, had a history of sensitivity to cephalosporins, were using another drug that could have interacted with the study medication, had a serious and/or chronic illness/underlying disease e.g. organ impairment/failure (kidney, liver), were clinically severely immunocompromised, and/or had chronic obstructive pulmonary disease. Female patients were excluded if they were breast feeding, pregnant or were of child-bearing potential and were not willing to use a barrier method of contraception in addition to their normal contraception (if any) during the course of the study.

\section{Treatment}

Two formulations of cefpodoxime were administered, Orelox ${ }^{\circledast}$ (Aventis Pharma (Pty) Ltd, 2 Bond Street, Midrand, South Africa) and Cepodem ${ }^{\circledast}$ (Ranbaxy (SA) (Pty) Ltd, Ground Floor, Tugela House, Riverside Office Park, 1303 Heuwel Avenue, Centurion, South Africa). Patients diagnosed with tonsillitis received $1 \mathrm{x}$ $100 \mathrm{mg}$ cefpodoxime tablet twice daily for ten days. Patients diagnosed with sinusitis or pneumonia received $2 \times 100 \mathrm{mg}$ cefpodoxime tablets twice daily for ten days according to the registered indications and dose.

\section{Sample size}

A total sample size of 90 patients randomised in a 1:1 ratio to treatment with the generic formulation or the brand name product was proposed. Demographic data were summarised by descriptive statistics: sample size, mean, standard deviation, median, minimum and maximum values for continuous variables, and frequency counts and percentages for categorical variables. The clinical and bacteriological cure rates were calculated for each treatment arm. In each treatment arm, adverse events were monitored and listed by type, severity, relatedness to the study medication, duration, and action taken. The investigators were blinded to the treatment allocations. Unique randomisation numbers were allocated to all medication prior to delivery to the respective sites. The randomisation sequence was generated by a biostatistician and investigators remained blinded to allocation for the duration of the study.

\section{Endpoints}

The primary endpoint was to compare overall effectiveness of the generic formulation to the non-generic formulation of cefpodoxime in all evaluable patients. Efficacy was measured by the clinical cure rate for patients who returned at the end-oftherapy visit and had resolution of fever and other presenting clinical symptoms and who did not require an additional course of antibiotics. Clinical outcome was considered as indeterminate when the patient withdrew prematurely, displayed lack of compliance, or developed another secondary infection. Bacteriological cure implied that the significant bacteria that was microbiologically identified from a representative respiratory sample at the enrolment visit from the respiratory tract of the patient, was microbiologically eradicated at the end-of-therapy visit. A sputum sample was taken in patients with communityacquired pneumonia. A throat swab was done on patients with tonsillo-pharyngitis and no sample specimen was taken from patients with sinusitis as sinus taps were not done routinely as per current clinical practice. The secondary endpoints assessed the safety and the tolerability of the generic versus the non-generic formulation (i.e. measuring the number, severity, and frequency of adverse events; the number of patients who withdrew due to adverse events; the number of patients who did not complete a full course of therapy as determined by a diary card).

\section{Assessment}

All enrolled patients completed a baseline visit upon enrolment and a follow-up visit after the end of therapy. Patients diagnosed with any one of the three conditions had their end-of-therapy visit between day 11 and day 13 to coincide with treatment. (A two-day window period was allowed logistically for patients to attend visit two.) Patients were required to complete a diary card of adverse effects and adherence to therapy. After the final study visit, a pill count was performed.

\section{Statistical analysis}

The data from the three participating practices, as well as for the three clinical diagnosis sites of infection, were combined for purposes of the statistical analysis. Comparisons of sites, or of infection types, were not objectives of the study. Continuous variables were summarised by sample size, mean, standard deviation, minimum and maximum values. Categorical variables were summarised by frequency counts and percentages. The statistical analysis was performed by ClinStat CC, Pretoria, South Africa. All analyses were carried out on $\mathrm{SAS}^{\circledR}$, Release 9.1.3, run under Microsoft ${ }^{\circledast}$ Windows $^{\circledR}$ Vista $^{\circledR}$ Business for a personal computer, and $\mathrm{p}$ values $<0.05$ were considered significant. The study was not statistically powered to demonstrate non-inferiority. However, it was appropriately powered to demonstrate a difference if present. 


\section{Results}

A total of 90 patients were enrolled in the study: Orelox ${ }^{\oplus} n=45$ and Cepodem ${ }^{\circledast} n=45$. Of the total number of patients enrolled, 18 were diagnosed with sinusitis, 54 had tonsillo-pharyngitis and 18 had pneumonia. All 90 patients complied with the inclusion and exclusion criteria and had completed informed consent before enrolment in the study. Of the 90 patients enrolled, 86 (Cepodem ${ }^{\circledast}$ arm: $\mathrm{n}=43$; Orelox ${ }^{\circledast}$ arm: $\mathrm{n}=43$ ) attended visit two (completed the study) and were assessable for bacteriological and clinical cure. Two patients on each arm were lost to follow-up (Cepodem ${ }^{\circledast}$ arm $n=2$, Orelox ${ }^{\circledast}$ arm $n=2$ ). None of the patients withdrew from the study due to adverse events. The mean age of participants in the study for Cepodem ${ }^{\circledast}$ and Orelox ${ }^{\circledR}$ was 42 and 34 years respectively. The gender ratio for Cepodem ${ }^{\circledast}$ and Orelox ${ }^{\circledast}$ did not differ significantly. See Table II for patient demographics.

Table II. Summary of demographics

\begin{tabular}{lccc}
\hline \multicolumn{1}{c}{ Characteristic } & $\begin{array}{c}\text { Cepodem }^{\circledR} \\
(\mathbf{n}=\mathbf{4 5})\end{array}$ & $\begin{array}{c}\text { Orelox }^{\circledR} \\
(\mathbf{n = 4 5 )}\end{array}$ & $\begin{array}{c}\text { All } \\
(\mathbf{n = 9 0 )}\end{array}$ \\
\hline Age, years: Mean (SD) & $43(12)$ & $34(11)$ & $39(12)$ \\
Gender: Males & 26 & 34 & 60 \\
Females & 19 & 11 & 30 \\
\hline
\end{tabular}

Cure rates were calculated at the end of the treatment and were based on clinical cure at visit two as well as bacteriological cure. The cure rates are shown in Table III.

Table III. Clinical and bacteriological cure rates*

\begin{tabular}{lccc}
\hline \multirow{2}{*}{ Clinical cure rate } & \multicolumn{3}{c}{ Number (\%) of patients } \\
\cline { 2 - 4 } & Cepodem $^{\circledR}$ & Orelox $^{\circledR}$ & All \\
\hline No & - & $1(2.3)$ & $1(1.2)$ \\
Yes & $43(100)^{*}$ & $42(97.7)^{*}$ & $85(98.8)$ \\
Total & $\mathbf{4 3 ( 1 0 0 )}$ & $\mathbf{4 3 ( 1 0 0 )}$ & $\mathbf{8 6 ( 1 0 0 )}$ \\
\hline Bacterial cure rate & & & \\
No & $2(7.1)$ & $4(12.9)$ & $6(10.2)$ \\
Yes & $26(92.9)^{*}$ & $27(87.1)^{*}$ & $53(89.8)$ \\
Total & $\mathbf{2 8 ( 1 0 0 )}$ & $\mathbf{3 1 ( 1 0 0 )}$ & $\mathbf{5 9 ( 1 0 0 )}$ \\
\hline
\end{tabular}

Forty-two (97.7\%) patients in the Orelox ${ }^{\circledR}$ arm and 43 (100\%) in the Cepodem $^{\circledast}$ arm were shown to be clinically cured. Approximately 144 respiratory samples (108 throat swabs and 36 sputum specimens) were collected from patients with tonsillitis and pneumonia. The results of the bacteriological cure rates showed high rates in this study with $27(87.1 \%)$ in the Orelox ${ }^{\circledR}$ arm and $26(92.9 \%)$ in the Cepodem ${ }^{\circledR}$ arm. In this study, there was no statistically significant difference in cure rates for either product formulation of cefpodoxime.

Adverse events were graded according to the AIDS Clinical Trials Group (ACTG) adverse events guidelines. All 86 patients who completed the study were included in the analysis of adverse events. Adverse events were reported for 18 patients. Table IV illustrates the number of patients on Orelox ${ }^{\circledR}$ and Cepodem $^{\varpi}$ who experienced adverse events.
Table IV. Adverse events

\begin{tabular}{lccc}
\hline \multirow{2}{*}{ Events experienced } & \multicolumn{3}{c}{ Number (\%) of patients } \\
\cline { 2 - 4 } & Cepodem $^{\circ}$ & Orelox $^{*}$ & All \\
\hline No & $31(72.1)$ & $37(86.0)$ & $68(79.1)$ \\
Yes & $12(27.9)$ & $6(14.0)$ & $18(20.9)$ \\
Total & $\mathbf{4 3 ( 1 0 0 )}$ & $\mathbf{4 3 ( 1 0 0 )}$ & $\mathbf{8 6 ( 1 0 0 )}$ \\
\hline No statistically significant difference was detected & &
\end{tabular}

The most common adverse events for patients on Orelox ${ }^{\circledR}$ was dizziness (three patients) and for Cepodem ${ }^{\oplus}$ was abdominal pain (three patients), diarrhoea, dizziness and headache (two patients each). No other serious adverse events (SAEs) occurred during the study.

\section{Discussion}

This exploratory study demonstrated that there is no significant difference in clinical or bacteriological cure rates between Orelox ${ }^{\oplus}$ tablets and Cepodem ${ }^{\oplus}$ tablets. There is also no significant difference in the safety and tolerability of both formulations of cefpodoxime.

Many clinical studies of oral cephems performed between 1988 and 1992 revealed the consistent effectiveness of the so-called third generation molecules against the pathogens commonly associated with community-acquired respiratory tract infections. ${ }^{16-19}$

However, a clinical diagnosis of infection and the ensuing improvement of symptoms after the use of any empirically prescribed antimicrobial agent is not proof of efficacy, because it could have been a viral infection, which would have cleared up in any case.Consequently, in this study, it was decided to utilise throat swabs and sputum samples as a marker to test bacteriological effectiveness and also provide bacteriological samples to support the clinical outcome. ${ }^{20}$ It was clearly demonstrated that clinical cure rates correlate with bacteriological cure rates in every day clinical practice in the treatment of ambulatory patients with upper and lower respiratory tract infections. The study, in spite of the limitations of obtaining swabs from all patients, especially those with sinusitis, was able to highlight the effectiveness of the use of a commonly prescribed oral third generation cephalosporin; it also demonstrated similar outcomes and tolerably in the same setting for products from different manufacturers i.e. one originator and one generic. This outcome further supports the bioequivalence data of Cepodem ${ }^{\circledast}$ in that bioequivalence translates into clinical effectiveness.

\section{Conclusion}

Both Orelox ${ }^{\circledast}$ and Cepodem ${ }^{\circledast}$ are used widely in private practice community settings in South Africa in the empirical treatment of patients with respiratory tract infections. The high bacteriological and clinical cure rates together with the tolerability of both formulations should serve as a good basis for the selection of either in clinical practice, when indicated. This study supports the bio-equivalence data of the multisource product clearly demonstrating that in-vivo PK/PD modelling translates into clinical efficacy and argues against the roll-out of a non- 
inferiority study. Non-inferiority studies should therefore only be considered when bio-equivalence cannot be guaranteed.

\section{Disclosure}

The authors report no conflicts of interest in this work.

\section{Acknowledgements}

This research was financially supported by Ranbaxy (SA) (Pty) Ltd. We thank Prof HS Schoeman for assistance with the statistical analysis. We are also immensely grateful to Prof MP Grobusch, Dr M Henning, Dr MR Hire, Dr I Lingoomiah and Dr D Nana for their assistance with the study.

\section{References}

1. Devi P, Rutledge PJ. Cyclobutanone analogues of $\beta$-lactam antibiotics: $\beta$-lactamase inhibitors with untapped potential? ChemBioChem [Internet]. 2017 Feb 16 [cited 2018 Sep 20];18(4):338-51. Available from: http://www.ncbi.nlm. nih.gov/pubmed/27992105

2. Sader HS, Jones RN. Cefdinir: an oral cephalosporin for the treatment of respiratory tract infections and skin and skin structure infections. Expert Rev Anti Infect Ther [Internet]. 2007 Feb 10 [cited 2018 Sep 20];5(1):29-43. Available from: http://www.ncbi.nlm.nih.gov/pubmed/17266451

3. Schito GC, Keenan MHJ. Predicting the clinical efficacy of generic formulations of ceftriaxone. J Chemother [Internet]. 2005 Sep 13 [cited 2018 Sep 20];17(sup2):33-40. Available from: http://www.ncbi.nlm.nih.gov/ pubmed/16315582

4. Zamoner W, de Freitas FM, Garms DSS, de Oliveira MG, Balbi AL, Ponce D. Pharmacokinetics and pharmacodynamics of antibiotics in critically ill acute kidney injury patients. Pharmacol Res Perspect [Internet]. 2016 Dec [cited 2018 Sep 20];4(6):e00280. Available from: http://www.ncbi.nlm.nih.gov/ pubmed/28097012

5. Al-Metwali B, Mulla H. Personalised dosing of medicines for children. J Pharm Pharmacol [Internet]. 2017 May [cited 2018 Sep 20];69(5):514-24. Available from: http://www.ncbi.nlm.nih.gov/pubmed/28266713

6. Auckenthaler R. Pharmacokinetics and pharmacodynamics of oral beta-lactam antibiotics as a two-dimensional approach to their efficacy. J Antimicrob Chemother [Internet]. 2002 Jul [cited 2018 Sep 20];50 Suppl:13-7. Available from: http://www.ncbi.nlm.nih.gov/pubmed/12077155

7. Abel Zur Wiesch P, Clarelli F, Cohen T. Using chemical reaction kinetics to predict optimal antibiotic treatment strategies. PLoS Comput Biol [Internet]. 2017 [cited 2018 Sep 20];13(1):e1005321. Available from: http://www.ncbi.nlm.nih.gov/ pubmed/28060813

8. Cilveti R, Olmo M, Pérez-Jove J, Picazo J-J, Arimany J-L, Mora E, et al. Epidemiology of otitis media with spontaneous perforation of the tympanic membrane in young children and association with bacterial nasopharyngeal carriage, recurrences and pneumococcal vaccination in Catalonia, Spain - The Prospective HERMES Study. Miyaji EN, editor. PLoS One [Internet]. 2017 Feb 1 [cited 2018 Sep 20];12(2):e0170316. Available from: http://www.ncbi.nlm.nih. gov/pubmed/28146590
9. Cohen R. Clinical efficacy of cefpodoxime in respiratory tract infection. J Antimicrob Chemother [Internet]. 2002 Jul [cited 2018 Sep 20];50 Suppl:23-7. Available from: http://www.ncbi.nlm.nih.gov/pubmed/12077157

10. Ghosh A, Jana U, Khaowas A, Das S, Mandal A, Das N. Comparison of the effectiveness and safety of cefpodoxime and ciprofloxacin in acute exacerbation of chronic suppurative otitis media: A randomized, open-labeled, phase IV clinical trial. J Pharmacol Pharmacother [Internet]. 2012 Oct [cited 2018 Sep 20];3(4):320. Available from: http://www.ncbi.nlm.nih.gov/pubmed/23326103

11. Fulton B, Perry CM. Cefpodoxime proxetil: a review of its use in the management of bacterial infections in paediatric patients. Paediatr Drugs [Internet]. 2001 [cited 2018 Sep 20];3(2):137-58. Available from: http://www.ncbi.nlm.nih.gov/ pubmed/11269640

12. Cazzola M, Matera MG, Donner CF. Pharmacokinetics and pharmacodynamics of newer oral cephalosporins. Clin Drug Investig [Internet]. 1998 Oct;16(4):335-46. Available from: https://doi.org/10.2165/00044011-199816040-00008

13. El-Shabrawi MH, Tolba OA, El-Adly TZ. Efficacy and safety of cefpodoxime in the treatment of acute otitis media in children. Egypt Pediatr Assoc Gaz [Internet] 2016 Jun [cited 2018 Sep 20];64(2):81-5. Available from: https://linkinghub. elsevier.com/retrieve/pii/S1110663815300185

14. Pistos C, Michalea S, Kalovidouris M, Kontopoulos G, Georgarakis M. Bioequivalence evaluation of 2 brands of cefuroxime axetil $250 \mathrm{mg}$ tablets in healthy human volunteers. Int J Clin Pharmacol Ther [Internet]. 2004 Jul [cited 2018 Sep 20];42(7):367-72. Available from: http://www.ncbi.nlm.nih.gov/ pubmed $/ 15605688$

15. Tuntland T, Ethell B, Kosaka T, Blasco F, Zang RX, Jain M, et al. Implementation of pharmacokinetic and pharmacodynamic strategies in early research phases of drug discovery and development at Novartis Institute of Biomedical Research. Front Pharmacol [Internet]. 2014 Jul 28 [cited 2018 Sep 20];5:174. Available from: http://www.ncbi.nlm.nih.gov/pubmed/25120485

16. Briggs BM, Jones RN, Erwin ME, Barrett MS, Johnson DM. In vitro activity evaluations of cefdinir (FK482, Cl-983, and PD134393). A novel orally administered cephalosporin. Diagn Microbiol Infect Dis [Internet]. [cited 2018 Sep 20];14(5):425-34. Available from: http://www.ncbi.nlm.nih.gov/ pubmed/1797457

17. Gerlach EH, Jones RN, Allen SD, Koontz FP, Murray PR, Pfaller MA, et al. Cefdinir (FK482), an orally administered cephalosporin in vitro activity comparison against recent clinical isolates from five medical centers and determination of MIC quality control guidelines. Diagn Microbiol Infect Dis [Internet]. 1992 Aug [cited 2018 Sep 20];15(6):537-43. Available from: http://www.ncbi.nlm.nih.gov/ pubmed/1424507

18. Inamoto $\mathrm{Y}$, Chiba T, Kamimura T, Takaya T. FK 482, a new orally active cephalosporin synthesis and biological properties. J Antibiot (Tokyo) [Internet] 1988 Jun [cited 2018 Sep 20];41(6):828-30. Available from: http://www.ncbi.nlm. nih.gov/pubmed/3255303

19. Sader HS, Jacobs MR, Fritsche TR. Review of the spectrum and potency of orally administered cephalosporins and amoxicillin/clavulanate. Diagn Microbiol Infect Dis [Internet]. 2007 Mar [cited 2018 Sep 20];57(3):S5-12. Available from: http:// www.ncbi.nlm.nih.gov/pubmed/17292577

20. Baron EJ, Miller JM, Weinstein MP, Richter SS, Gilligan PH, Thomson RB, et al. Executive summary: a guide to utilization of the microbiology laboratory for diagnosis of infectious diseases: 2013 Recommendations by the Infectious Diseases Society of America (IDSA) and the American Society for Microbiology (ASM)a. Clin Infect Dis [Internet]. 2013 Aug 15 [cited 2018 Sep 20];57(4):485-8. Available from: http://www.ncbi.nlm.nih.gov/pubmed/23881727 